\title{
Developing mathematical exercise software for visually impaired students
}

\author{
Janu Arlinwibowo a *, Yunus Mustaqim ${ }^{\text {b }}$, Agung Prihandono ${ }^{c}$, Fida Maisa Hana ${ }^{d}$, \\ Achmad Ridwan ${ }^{e}$, Ade Ima Afifah Himayati ${ }^{f}$ \\ Universitas Muhammadiyah Kudus. Jl. Ganesha Raya No.I, Purwosari, Kudus, 59316, Indonesia \\ a janu@umkudus.ac.id; ${ }^{\mathrm{b}}$ yunusmustaqim@umkudus.ac.id; ${ }^{\mathrm{c}}$ agungdono@umkudus.ac.id; ${ }^{\mathrm{d}}$

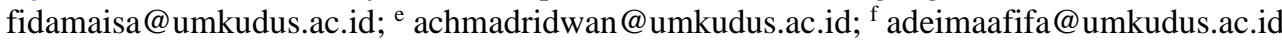 \\ * Corresponding Author.
}

Received: 10 March 2021; Revised: 7 April 2021; Accepted: 15 April 2021

\begin{abstract}
This study aims to develop a math test exercises application based on Android for the visually impaired. This research is development research carried out with research steps, namely: (1) preliminary research, (2) prototyping stage, and (3) assessment phase. The research was conducted between April 2020 and December 2020. The material chosen in the application developed was a plan that was taught in 8 grade. The research process involved six experts in assessing the product, namely three mathematics education experts to assess the validity of the aspects of mathematical content, two visually impaired education experts to assess visually impaired content suitability and accessibility, and 1 IT expert to assess product performance. The product was tested on nine visually impaired. The quality of teaching materials is based on three basic aspects, namely feasibility, practicality, and effectiveness. The conclusions of this study are: (1) the product has good quality because it has been declared feasible by experts, practical, which can be seen from the enthusiastic response and student testimonials, and is effective because it can be used to learn and measure abilities, (2) the application is divided into three sections, preamble (contains the opening tune and instructions for use), practice questions, and results. Application development is based on two elements, namely accessibility and compatibility of the content with the cognition of the visually impaired, (3) the question page consists of questions (will be read when entering the page and can be repeated when the user taps the question section), under the question, there is a question number. There is a question; answer choices are arranged twice in two (the answer choices will be read out when pressed by the user). There is an answer lock button at the very bottom, and (4) the visually impaired wants an application with a simple operating system, provides challenges to the user, and has two functions, namely measuring their abilities and facilitating their learning.
\end{abstract}

Keywords: Visually Impaired, Math, Math Exercises, Application, Android

How to Cite: Arlinwibowo, J., Mustaqim, Y., Prihandono, A., Hana, F., Ridwan, A., \& Himayati, A. (2021). Developing mathematical exercise software for visually impaired students. Psychology, Evaluation, and Technology in Educational Research, 3(2), 77-88. doi:http://dx.doi.org/10.33292/petier.v3i2.81

\section{INTRODUCTION}

Visually Impairment is a type of diffable with limited vision (Arlinwibowo \& Retnawati, 2015). Moderate visual Impairment is indicated by acuity around 20/70 to 20/160 and severe disturbances, namely visual acuity less than 20/160 (Westwood, 2009). The first category is known as low vision, and the second category is known as total blindness. Low vision is visually impaired with limited vision, and total blindness is visually impaired and cannot access visual information (Roe \& Webster, 2002). Two things that are affected by visual Impairment are mobility and (Stanimirov et al., 2020; Westwood, 2009). In general, $80 \%$ of the information captured by humans comes from the sense of sight (DoE, 2011). Based on this information, there is a significant difference in a visually impaired person's mobility and environmental orientation with others.

The problem is that the visually impaired are a minority. According to the $2012 \mathrm{WHO}$ data, the number of school-age visually impaired people is only around $1.02 \%$ (World Health Organization, 2012). Thus, various developments are oriented towards the majority of the population, namely the 
non-visually impaired. It is not uncommon for the needs and problems of the majority to be given more attention. Problems involving minority communities are often not realized so that they are not handled immediately. This situation can also be seen in the world of education. Many educational facilities cannot be accessed properly by visually impaired people (Arlinwibowo, Retnawati, Kartowagiran, \& Mustaqim, 2020), for example, such as various physics practicum tools (Arlinwibowo et al., 2018; Ratnaningtyas et al., 2011; Retnawati et al., 2018), mathematics learning media (Arlinwibowo \& Retnawati, 2015), and various other subjects that rely on the sense of sight to capture information. The majority of reading books in school libraries and public libraries as a learning resource for students are printed in alphabet letters so that the visual Impairment cannot access them.

Visually impaired learning facilities must maximize the senses that can function properly. Visual information that has been generally used as a source of information in learning should be transferred to others (Roe \& Webster, 2002). Visually impaired learning must maximize other senses that are still functioning properly, especially haptic and auditory (Hersh \& Johnson, 2008). Based on this information, all efforts can be made to provide learning resources so that visually impaired people can learn more comfortably. A lot of visual information can be converted into non-visual information so that it can be accessed by visually impaired people (Mani et al., 2005). Examples of such conversions are tactual audio media for learning mathematics (Arlinwibowo \& Retnawati, 2015), measuring instruments for physical quantities for the visually impaired (Ratnaningtyas et al., 2011), braille cards (Igirisa et al., 2019), interactive games (Sari et al., 2019), learning applications (Azmi et al., 2017), and many other innovations.

In the past, tactual media was the choice of many people to provide learning resources for the visually impaired. Illustrations were embossed, and the writing was converted to Braille. However, the Braille printing process is quite expensive when compared to printing the alphabet (Chowdhury et al., 2018; Sarkar \& Das, 2012), which hinders the process of procuring teaching materials in schools (Arlinwibowo, Retnawati, Kartowagiran, \& Mustaqim, 2020). The procurement of expensive learning facilities always collides with funding problems (Retnawati, Kartowagiran, et al., 2017). Technology is developing very fast (Arlinwibowo, Retnawati, \& Kartowagiran, 2020) and making things easier (Arlinwibowo, Retnawati, Kartowagiran, \& Kassymova, 2020; Hapsari et al., 2018). With technology, text information can be converted into voice so that it can be accessed by visually impaired people (Edward et al., 2018; Shetake et al., 2014; Venkateswarlu et al., 2016). However, changing text to audio cannot be implemented immediately because visually impaired people have different orientations (Pring, 2008; Salisbury, 2008) and experiences (Pandey, 2018). Thus, teaching materials must be made specifically with attention to the media and information content (Arlinwibowo \& Retnawati, 2015).

One of the subjects that have relied on visual information is mathematics (Retnawati, Arlinwibowo, et al., 2017; Trance et al., 2012). This is because mathematics is an abstract science (Putra et al., 2018), like geometry (Arlinwibowo \& Retnawati, 2015) which needs to be conveyed using various symbols and illustrations. Students must convert mathematical information into visual representations as well as concrete cases. Visual representations can make it easier for teachers to explain and students understand the material (Andriyani et al., 2018; Clements, 1999; Garderen et al., 2018). In addition, there are also mathematical symbols that simplify various situations mathematically (Cruz \& Smedt, 2013; Otte, 2018). In general, in understanding the symbol, the sense of sight has a dominant role compared to other senses. Visual information as the majority basis in learning makes it difficult for students to learn mathematics. The limitations of the learning process are very ironic because mathematics is a very important subject and equips students (Akhter \& Akhter, 2018). Various mathematics materials can equip students to face various problems in the real world (Dahiya, 2014; Mumcu, 2018). Without sufficient knowledge of mathematics, visually impaired people will have difficulty in various daily problems.

Improving learning facilities according to student needs is the keyword in improving the quality of education (Muhaidat et al., 2020; Retnawati, Hadi et al., 2017; Retnawati, Munadi, et al., 2017; Zurqoni et al., 2018). Providing accessible learning facilities for people with disabilities is an effort so that students with disabilities can learn easily and are able to maximize their potential (Arlinwibowo \& Retnawati, 2015). Test exercise is a medium to facilitate student learning. However, so far, the scattered mathematics test exercises have not been done by considering the various needs of the 
visually impaired. Mathematics test exercises can be used to train students' ability to solve problems, measure their existing competencies, as well as prepare for the real test. Thus, providing accessible practice questions for the visually impaired can help visually impaired students deepen their understanding of mathematics.

Accessibility should be used as a guide in product development for the visually impaired. Thus, the practice of math problems must be easily accessible and contain a suitable context for the visually impaired students' experience. Technological support allows the test to be packaged in a program that has effectiveness in use (Arlinwibowo, Retnawati, Hadi, et al., 2021), and data can be analyzed in more detail (Arlinwibowo, Achyani, \& Kurniadi, 2021). In 2015 (Arlinwibowo \& Retnawati, 2015) developed audio teaching materials, they are still saved on a flash disk. In the current era of technology, it is possible to implement a practice question application that can facilitate the visually impaired. The smartphone is a potential thing to be used as a learning medium. According to BPS data for 2019, mobile phone users in Indonesia reached $63.53 \%$ of the total population (BPS, 2020). Nowadays, visually impaired mobile phones can be operated as well (Griffin-Shirley et al., 2017; Rodrigues et al., 2015). Android is the platform chosen to create a question practice application because it is very popular and the choice of many people (Saefi et al., 2017; Said et al., 2018; Tamhane et al., 2015). Thus this study aims to develop an Android-based math problem practice application for the visually impaired. It is hoped that this application can facilitate the visually impaired to learn mathematics through practice questions.

\section{METHOD}

This research is development research carried out with research steps that adopt the developed model (Plomp, 2013), namely: (1) preliminary research: needs and context analysis, literature review, developing conceptual and theoretical frameworks for research, (2) prototyping stage: the design process cyclically and sequentially in the form of a more micro research process and using formative evaluation to improve and improve the product, and (3) assessment phase: semi summative evaluation to conclude whether the solution or intervention is what you want and make recommendations product development.

The research was conducted between April 2020 and December 2020. The research was carried out in various places, namely the research house, Utak Home Recording, Muhammadiyah University of Kudus, and the virtual room (google meet). The mathematics material chosen as the question content is plane which is taught in grade 8 . The research process involved six experts in assessing the product, namely three mathematics education experts (EM1, EM2, and EM3) to assess the validity of the aspects of mathematics content, two experts visually impaired education (EB1 and EB2) to assess the suitability of the visually impaired content and accessibility, and 1 IT expert (ET1) to assess product performance. The researcher provides a validation sheet that is filled in by the validator. The results of the validation from several validators concluded that various suggestions were used as the basis for making revisions.

Research involving visually impaired people has limited respondents and sources, so that in order to produce an in-depth discussion, the research focuses on collecting qualitative data. Data collection techniques are observation and interviews to explore product performance information in depth from teachers and visually impaired students. The product was tested on nine visually impaired students (T1, T2, T3, T4, T5, T6, T7, T8, T9), all of which were totally visually impaired students. Visually impaired students access the application via each student's android smartphone. Qualitative data from data collection were analyzed using a model developed by Miles and Huberman. The research data analysis step starts from data collection, data reduction, data presentation, and concluding (Miles \& Huberman, 1994).

\section{RESULTS AND DISCUSSION}

The product was developed based on preliminary analysis with data sources such as interviews, observations, and literature studies. Several crucial things become obstacles to learning for visually impaired people, namely independent learning, the specificity of students' cognitive experiences, various learning materials using illustrations that are far from visually impaired (Arlinwibowo \& Retnawati, 2015), and limited learning facilities (Arlinwibowo et al., 2018). Smartphones have great 
potential to facilitate the visually impaired in learning. Android smartphones offer a wide variety of assistive applications using the built-in sensors of the mobile device (Csapó et al., 2015). The results of this study are a development product in the form of an Android-based math problem practice application. Thus, the existence of an Android math problem practice application can minimize the limitations of learning resources and increase student learning independence. The math problem practice application is a math problem practice application specifically designed for the visually impaired. Things to consider in developing questions are the accessibility of information modes, the content of the material, and the structure of the application. Thus, the basic mode of information used is audio and material content adjusted to visually impaired students' cognitive experience. The built-in hardware of mobile devices has a lot of potentials that can be developed (Csapó et al., 2015). Technology makes learning easier (Larkin \& Calder, 2016), and (Daroni et al., 2018) find the fact that technology can help visually impaired people learn mathematics. Regarding the application structure, this research tries to create a system that is easy to operate and can attract visually impaired students to use the application.

The development process begins with conducting a curriculum study and selecting a sample of basic competencies (KD). In this development, the researcher chose KD 3.6, which is to identify the properties of a plane and use it to determine the perimeter and area, and 3.7, which is to estimate and calculate the surface area of an irregular shape by applying geometric principles. The two basic competencies are described in 12 indicators which serve as the basis for making 24 questions. All questions were made by considering the cognitive experience of visually impaired students so that KD achievement can be measured accurately. Accurate is meant if students are not able to work on the questions; it is because they do not master KD, not because they are not familiar with the context of the questions. For example, visually impaired people do not understand the shape of the bridge, so if they are given a question in the context of the bridge, they will find it difficult to construct the shape of the bridge in their minds. Lack of cognitive experience related to bridges makes the process of solving questions more complicated so that students are prone to making mistakes in solving problems, not because they do not understand mathematical solutions but because they do not master the context.

The questions are arranged in alphabetical writing as well as a script. The question script was developed as a starting material in developing Android-based practice questions. The question script was developed by paying attention to (1) the suitability of the questions to the indicators, (2) the context of the questions according to the cognition experience of the visually impaired, and (3) the language used according to the level of the student as the product target. The question script was then reviewed by two mathematical education experts and obtained input for additional information on various mathematical symbols, for example, "... a square with a side length of $10 \mathrm{~cm} 2$ (read: ten square centimetres)". The revision was made to anticipate if the selected narrator was not someone with a mathematics education background. The rest of the two experts stated that related to the instrument's content, it represented indicators, the questions were clearly formulated, there was one single answer, all questions had compatibility with the keys, and the illustrations in the questions were in accordance with the students' conditions. Meanwhile, with regard to language, the two experts agree that the language used is communicative, according to the correct spelling of Indonesian, and in accordance with the condition of the students.

The final script is in the recording process. The recording process involves the narrator, who has a background in mathematics education and has various experiences in public events. Thus, it is hoped that the question content can be conveyed well, the sound output is good, and there is minimal repetition when voting. The production process is carried out at Utak Home Recording in Karangwaru Lor TRII no. 2309 Yogyakarta. In the audio file production process, the researcher is assisted by a sound engineer who is a professional in the audio recording field. The recording process is done over and over again to get a clear sound. The recording process can be completed within 2 hours. After the recording process is complete, the clear and less clear parts are sorted. Sound parts that contain noise are edited with logic pro software so that they become clear and comfortable for students to listen to.

The audio file is then re-entered in the validation process by the mathematics education expert. From the validation results, the audio component has been declared valid. However, there is one revision, namely the addition of opening and closing tones. Then the researcher involved a jingle composer to fill the tone in audio teaching materials. The opening and closing music are used as 
markers as well as variations in the process of solving the questions. Thus, the audio material is ready to enter the Android platform into a question practice application.

The next step is to create an Android-based mathematics test exercise application with audio files that have been declared valid by the validator. The audio file has been submitted to the programmer, whose task is to package the file on the Android platform to operate on any Android smartphone. The process of preparing the application construction has been completed, but there are still several parts that need to be improved, namely the audio output and the correction system for each question. Researchers communicate intensively with programmers to produce applications that have readability and easy access for visually impaired students.

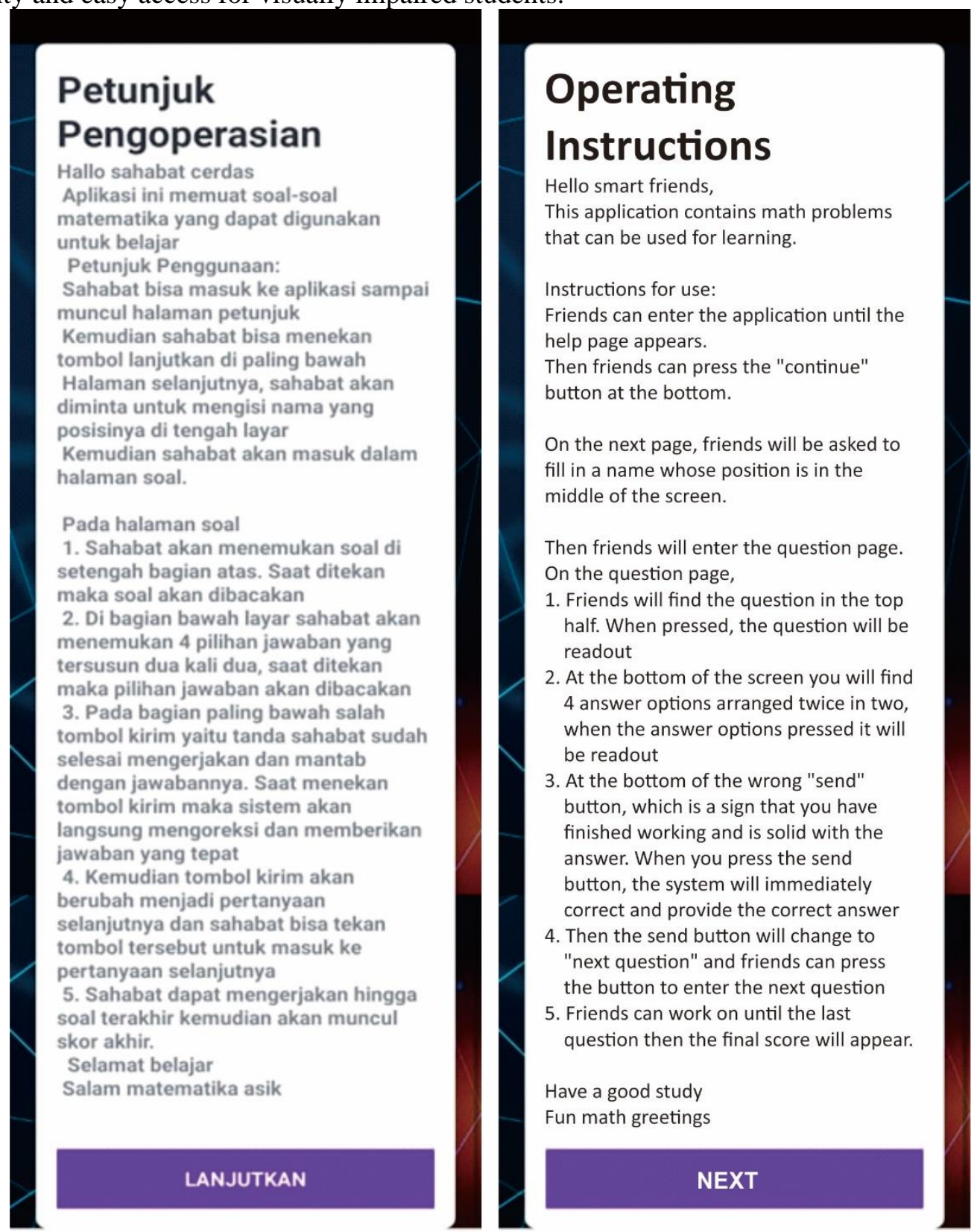

Figure 1. Original version (left) and English translation (right)

The application master is made in an apk format that can be installed on an android-based smartphone. Before installing, the system in the smartphone is first set to recognize unknown sources. Then the master application can be installed on a smartphone with a shortcut that says J-Quiz. The shortcut can be clicked, and then the question practice application opens, which is the product of this research. The product was validated by three experts, namely one math teacher who has experience 
teaching visually impaired students, one visually impaired special education teacher, and one expert in the field of information technology. The three validators agreed that the application product was feasible to use. The following is a description of each section in the application.

The opening will begin with an opening tune, and the screen will open the operating instructions, which will voice the operation instructions if clicked. The opening display is as shown in Figure 1. The continue button is a button that has a command function to move to the next page, which is a page to fill in student identities. The identity field is right in the middle of the screen. Identity can be filled with the application user name. The following is a display of the identity content page of the question practice application.
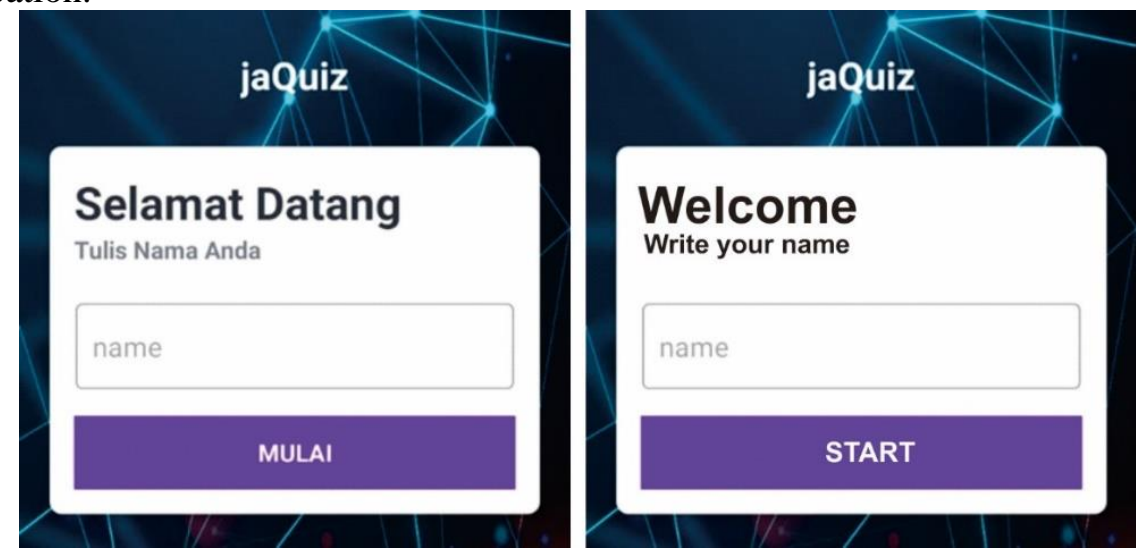

Figure 2. Original version (left) and English translation (right)

The next stage is that students will enter the question page. The question page consists of 3 parts: questions (top), four answer choices arranged twice in two, and at the bottom, there is a button to enter the next question. The system will read out the questions when the user presses the questions, and the answer choices will be read out when pressed by the user. The answer choices will be read aloud and change display when pressed. To lock the answer choices, the user can press the "send" button at the very bottom. When the button is pressed, the answer is locked, and the system will show the answer key, then the "send" button changes to "next question". The following is an illustration of the description above.

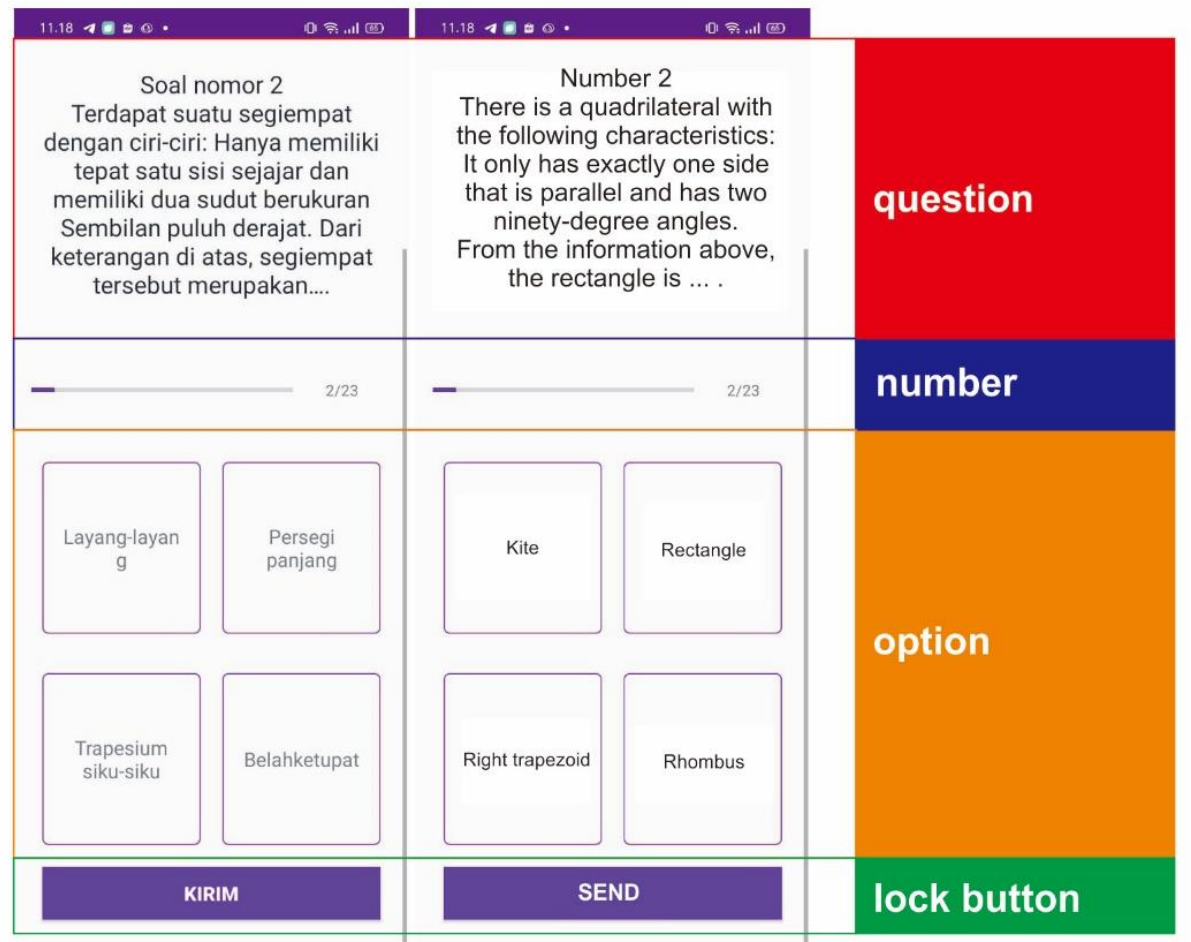

Figure 3. Structure in the question page (original page and pages that have changed in English) 

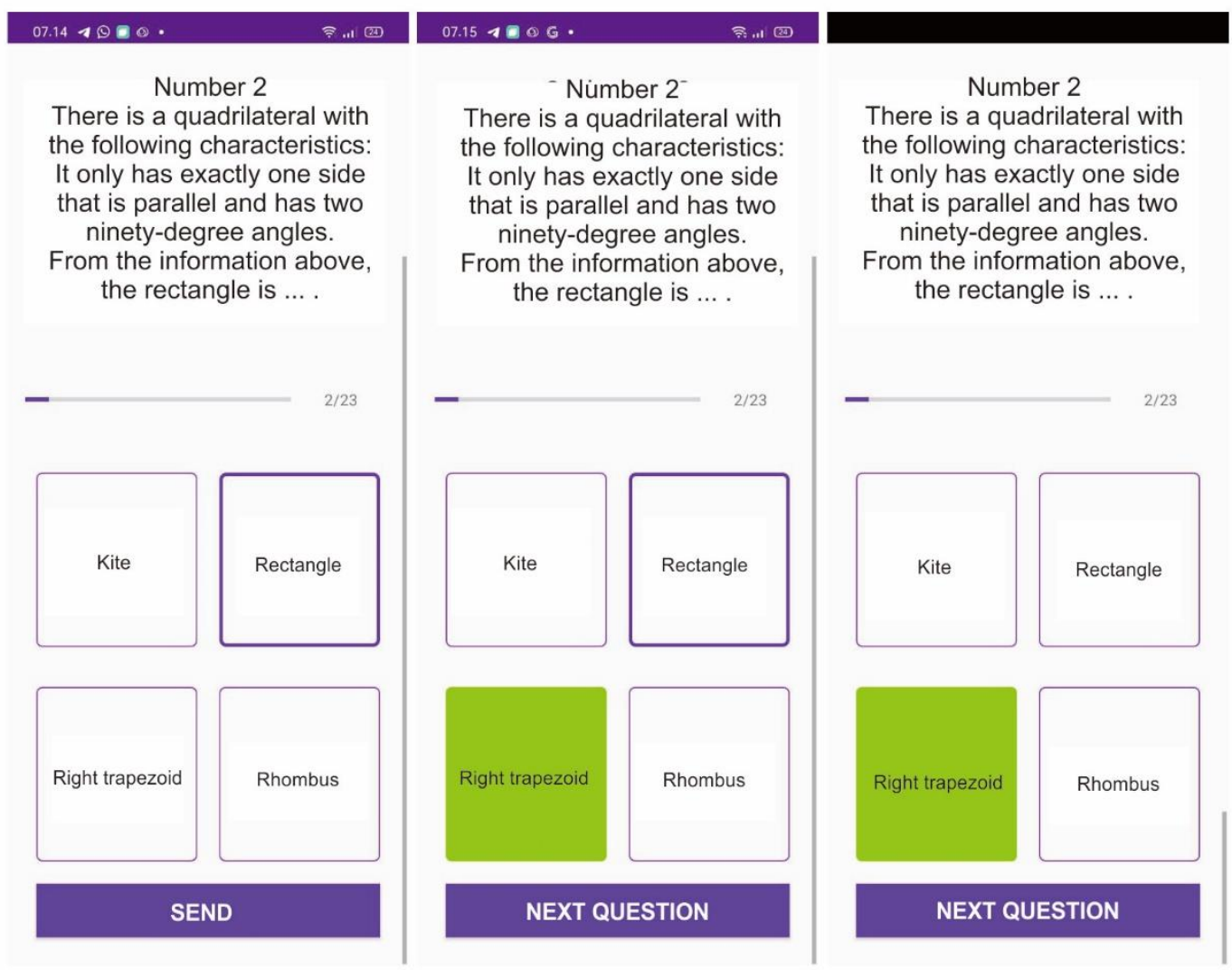

Figure 4. When the option is pressed (left) when the user answers wrong (centre), and when the user answers correctly (right)

The user is directed to solve up to the 23rd question. Then at the end, a recap of the results of the work and the final value of the user will be given.

The application was tested on nine visually impaired people. The trial results showed that all students responded well to the creation of a math exercise test application. Respondents said that the math exercise test application could be their medium in learning and measuring understanding of the plane. Systemically, the application can be used properly, without any problems. Respondents said that the math exercise test application could be a medium in learning and measuring understanding of the geometry of flat shapes. All users can easily understand the instructions for use, access all questions, choose answers, find answer keys, and find out work results. However, based on discussions with the visually impaired, there are several suggestions for improving the application whose aim is not only accessibility but also product attractiveness. The following is input provided by nine visually impaired people.

First, Remove the "next" button and replace it with the sliding mode. Removing the "next" button and changing it to the sliding mode can make the application even simpler. The simpler the application, the more comfortable the visually impaired will be in operating (T,epelea et al., 2014). The simplicity of an application has a good impact when coupled with attractiveness (Sayal et al., 2020; Supandi et al., 2018).

Second, make the questions read out immediately at the turn of the page. Previously, users moved pages and had to press the part of the question so that the questions were readout. However, visually impaired people feel that the application will be easier to use when the questions are automatically read out when there is a change of question pages. However, users can repeat the reading of the question by pressing on the question section.

Third, Added a step explanation for finding the right answer when choosing a wrong answer. Previous applications were limited to showing the correct answer key when the user chose the wrong answer. Additional discussion will make students understand better by learning the route to finding the correct answer. Discussions can substitute the role of the teacher as a facilitator when students find it 
difficult (Arlinwibowo, Kistoro, Retnawati, et al., 2020). Thus, students can work on questions to measure self-efficacy (Erfan et al., 2020) as well as learn related materials that have not been mastered. A concept that can measure students 'abilities and improve students' abilities is considered effective (Baas et al., 2015).

Fourth, Increase the number of items in the question bank. Visually impaired students said that the more questions, the better because it means there are many variations of the questions (Pramono \& Retnawati, 2020). Thus, application users will always feel challenged working on problems in the application because they always find new challenges (questions).

Fifth, Provide a package of questions arranged in stages. Participants who are students with disabilities said that the application should continuously provide packages of questions, starting from the easiest to the most difficult levels. If the application user can complete a certain package with a certain threshold, then he will be directed to enter the package of more difficult questions. Thus students become challenged to continue learning and reach higher levels. The math test exercise application is good if it contains a challenge so that it spurs users to continue learning (Supandi et al., 2018).

\section{CONCLUSION}

The conclusions of this study are: (1) the product has good quality because it has been declared feasible by experts, fulfils practical aspects that can be seen from the enthusiasm of respondents and student positive testimonials, and is effective because it can be used to learn and measure abilities and (2) divided applications into three parts, opening (containing the opening tune and instructions for use), practice questions, and results. Application development is based on two elements, namely accessibility and compatibility of the content with the cognition of visually impaired students, (3) the question page consists of questions (will be read when entering the page and can be repeated when the user taps the question section), under the question there is a question number, then there is a question. Answer choices are arranged twice in two (the answer choices will be read out when pressed by the user). There is an answer lock button at the very bottom, and (4) visually impaired people want an application that has a simple operating system, provides challenges to the user and has two functions, namely measuring their abilities and facilitating their learning.

\section{ACKNOWLEDGMENT}

We would like to thank the Deputy for Strengthening Research and Development, Ministry of Research and Technology/Research and Innovation Agency, for facilitating this research in the form of funding through the Beginner Lecturer Research (Penelitian Dosen Pemula/PDP) scheme.

\section{REFERENCES}

Akhter, N., \& Akhter, N. (2018). Learning in mathematics : Difficulties and perceptions of students. Journal of Educational Research, 21(1), 147-163.

Andriyani, Budayasa, I. K., \& Juniati, D. (2018). The blind student's interpretation of two-dimensional shapes in geometry. Journal of Physics: Conference Series, 947, 012055. https://doi.org/10.1088/1742-6596/947/1/012055

Arlinwibowo, J., Achyani, I., \& Kurniadi, G. (2021). Multidimentional item respose utilization for validating mathematics national examination in Indonesia. Journal of Physics: Conference Series, 1764(1), 012113. https://doi.org/10.1088/1742-6596/1764/1/012113

Arlinwibowo, J., Kistoro, H. C. A., Retnawati, H., Kassymova, G. K., \& Kenzhaliyev, B. K. (2020). Differences between Indonesia and Singapore based on PISA 2015: Five-factor students' perception in science education. Jurnal Inovasi Pendidikan IPA, 6(1), 79-87. https://doi.org/10.21831/jipi.v6i1.32637

Arlinwibowo, J., \& Retnawati, H. (2015). Developing audio tactile for visually impaired students. International Journal on New Trends in Education and Their Implications, 6(4), 18-30. http://www.ijonte.org/FileUpload/ks63207/File/02.a.janu_arlinwibowo.pdf

Arlinwibowo, J., Retnawati, H., Hadi, S., Kartowagiran, B., \& Kassymova, G. K. (2021). Optimizing 
of item selection in computerized adaptive testing based on efficiency balanced information. Journal of Theoretical and Applied Information Technology, 99(4), 921-931.

http://www.jatit.org/volumes/Vol99No4/12Vol99No4.pdf

Arlinwibowo, J., Retnawati, H., \& Kartowagiran, B. (2020). The types of STEM education implementation in Indonesia. Journal of Xi'an University of Architecture \& Technology, XII(VIII), 606-613. https://www.xajzkjdx.cn/gallery/65-aug2020.pdf

Arlinwibowo, J., Retnawati, H., Kartowagiran, B., \& Kassymova, G. K. (2020). Distance learning policy in Indonesia for facing pandemic COVID-19: School reaction and lesson plans. Journal of Theoretical and Applied Information Technology, 98(14), 2828-2838.

https://pesquisa.bvsalud.org/global-literature-on-novel-coronavirus-2019ncov/resource/pt/covidwho-822222

Arlinwibowo, J., Retnawati, H., Kartowagiran, B., \& Mustaqim, Y. (2020). Inclusion schools in the Daerah Istimewa Yogyakarta Province, Indonesia: Regulations, facilities and aspirations of teachers. International Journal of Early Childhood Special Education, 13(1), 09-19. https://doi.org/10.9756/INT-JECSE/V13I1.211002

Arlinwibowo, J., Retnawati, H., \& Pradani, R. G. (2018). Constraints on the physics practicum for visually impaired students in inclusive junior high schools. 2nd International Conference on Tehacher Education and Professional Development, 83-90. https://doi.org/10.1201/9781315104188

Azmi, N., Maryono, D., \& Yuana, R. A. (2017). Development of an android-based learning media application for visually impaired students. IJIE (Indonesian Journal of Informatics Education), 1(1), 61-68. https://doi.org/10.20961/ijie.v1i1.11796

Baas, D., Castelijns, J., Vermeulen, M., Martens, R., \& Segers, M. (2015). The relation between Assessment for Learning and elementary students' cognitive and metacognitive strategy use. British Journal of Educational Psychology, 85(1), 33-46. https://doi.org/10.1111/bjep.12058

BPS. (2020). Telecommunication statistics in Indonesia 2010. Badan Pusat Statistika.

Chowdhury, D., Haider, M. Z., Sarkar, M., Refat, M., Datta, K., \& Fattah, S. A. (2018). An intuitive approach to innovate a low cost Braille embosser. International Journal of Instrumentation Technology, 2(1), 1-17. https://doi.org/10.1504/ijit.2018.090858

Clements, D. H. (1999). 'Concrete' manipulatives, Concrete ideas. Contemporary Issues in Early Childhood, 1(1), 45-60.

Cruz, H. De, \& Smedt, J. De. (2013). Mathematical symbols as epistemic actions. Synthese, 190, 3-19. https://doi.org/10.1007/s11229-010-9837-9

Csapó, Á., Wersényi, G., Nagy, H., \& Stockman, T. (2015). A survey of assistive technologies and applications for blind users on mobile platforms: a review and foundation for research. Journal on Multimodal User Interfaces, 9(4), 275-286. https://doi.org/10.1007/s12193-015-0182-7

Dahiya, V. (2014). Why study mathematics? Applications of mathematics in our daily life. International Journal of Innovative Science, Engineering \& Technology, 1(10), 411-422.

Daroni, G. A., Gunarhadi, G., \& Legowo, E. (2018). Assistive technology in mathematics learning for visually impaired students. Tadris: Jurnal Keguruan Dan Ilmu Tarbiyah, 3(1), 1-9. https://doi.org/10.24042/tadris.v3i1.2406

DoE. (2011). Teaching children who are blind or visually impaired inside. Government of Newfoundland and Labrador.

Edward, S., Jothimani. A, Jayaprakash.V, \& Xavier, J. B. (2018). Text-to-speech device for visually impaired people. International Journal of Pure and Applied Mathematics, 119(15), 1061-1067. https://www.acadpubl.eu/hub/2018-119-15/3/529.pdf

Erfan, M., Maulyda, M. A., Ermiana, I., Hidayati, V. R., \& Widodo, A. (2020). Validity and reliability of cognitive tests study and development of elementary curriculum using Rasch model. Psychology, Evaluation, and Technology in Educational Research, 3(1). https://doi.org/10.33292/petier.v3i1.51

Garderen, D. Van, Scheuermann, A., Poch, A., \& Murray, M. M. (2018). Visual representation in 
mathematics: Special education teachers' knowledge and emphasis for instruction. Teacher Education and Special Education, 41(1), 7-23. https://doi.org/10.1177/0888406416665448

Griffin-Shirley, N., Banda, D. R., Ajuwon, P. M., Cheon, J., Lee, J., Park, H. R., \& Lyngdoh, S. N. (2017). A survey on the use of mobile applications for people who are visually impaired. Journal of Visual Impairment and Blindness, 111(4), 307-323.

https://doi.org/10.1177/0145482x1711100402

Hapsari, S. I., Sugiyarto, K. H., \& Kosaka, N. (2018). An evaluation of application of information technology and communication of learning science with the theme of solar system. Psychology, Evaluation, and Technology in Educational Research, 1(1), 41. https://doi.org/10.33292/petier.v1i1.18

Hersh, M. A., \& Johnson, M. A. (2008). Assistive technology for visually impaired and blind people. Springer.

Igirisa, S. S., Fuad, Y., \& Ismail, S. (2019). Development of braille number card as learning media on integer materials for blind students. International Journal for Educational and Vocational Studies, 1(4), 268-272. https://doi.org/10.29103/ijevs.v1i4.1604

Larkin, K., \& Calder, N. (2016). Mathematics education and mobile technologies. Mathematics Education Research Journal, 28(1), 1-7. https://doi.org/10.1007/s13394-015-0167-6

Mani, M. N. G., Plernchivanich, A., Ramesh, G. R., \& Campbell, L. (2005). Mathematics made easy for children with visual Impairment. ICEVI.

Miles, M. B., \& Huberman, A. M. (1994). Qualitatif data analysis (2nd ed.). Sage Publications.

Muhaidat, M., Alodat, A. M., \& Almeqdad, Q. I. (2020). Inclusive education practices for refugee children with disabilities in Jordanian Schools. International Journal of Early Childhood Special Education (INT-JECSE), 12(2), 147-153. https://doi.org/10.9756/INT-JECSE/V12I2.201066

Mumcu, H. Y. (2018). Examining mathematics department students' views on the use of mathematics in daily life. International Online Journal of Education and Teaching, 5(1), 61-80. https://iojet.org/index.php/IOJET/article/view/221

Otte, M. (2018). The philosophy of mathematical education between Platonism and the computer. In P. Ernest (Ed.), The Philosophy of Mathematics Education Today (pp. 61-79). Springer. https://doi.org/10.1007/978-3-319-77760-3_4

Pandey, R. K. (2018). Comparative study of adjustment of visually impaired students. Universal Journal of Educational Research, 6(11), 2562-2571. https://doi.org/10.13189/ujer.2018.061121

Plomp, T. (2013). Educational design research: An introduction. In N. Nieveen \& T. Plomp (Eds.), Educational design research - Part A: An introduction (pp. 10-51). Netherlands Institute for Curriculum Development (SLO). http://international.slo.nl/publications/edr/

Pramono, A. J. B., \& Retnawati, H. (2020). Implementation of CAT in Indonesia school: Current challenges \& strategies. Universal Journal of Educational Research, 8(11), 5599-5609. https://doi.org/10.13189/ujer.2020.081164

Pring, L. (2008). Psychological characteristics of children with visual impairments: Learning, memory and imagery. The British Journal of Visual Impairment, 26(2), 161-171.

https://doi.org/10.1177/0264619607088279

Putra, J. D., Suryadi, D., \& Juandi, D. (2018). Mathematical abstraction ability of prospective math teacher students. Journal of Physics: Conference Series, 1132, 012049. https://doi.org/10.1088/1742-6596/1132/1/012049

Ratnaningtyas, D. I., Supriyani, R., Pertiwi, U. I., Badru, T., \& Arlinwibowo, J. (2011). Inovasi alat ukur besaran fisika berhuruf braille untuk melalui praktikum IPA [The innovation of physics measurement instruments based on braille through science practicum]. Prosiding Seminar Nasional Penelitian, Pendidikan Dan Penerapan MIPA, Fakultas MIPA, Universitas Negeri Yogyakarta, 339-344.

Retnawati, H., Arlinwibowo, J., \& Sulistyaningsih, E. (2017). The students' difficulties in completing geometry items of national examination. International Journal on New Trends in Education and Their Implications, 8(4), 28-41. 
http://www.ijonte.org/FileUpload/ks63207/File/03.heri_retnawati.pdf

Retnawati, H., Arlinwibowo, J., Wulandari, N., \& Pradani, R. (2018). Teachers' difficulties and strategies in physics teaching and learning that applying mathematics. Journal of Baltic Science Education, 17(1), 120-135. http://www.scientiasocialis.lt/jbse/?q=node/643

Retnawati, H., Hadi, S., Nugraha, A. C., Arlinwibowo, J., Sulistyaningsih, E., Djidu, H., Apino, E., \& Iryanti, H. D. (2017). Implementing the computer-based national examination in Indonesian School: The challenges and strategies. Problems of Education in The 21st Century, 75(6), 612633.

Retnawati, H., Kartowagiran, B., Arlinwibowo, J., \& Sulistyaningsih, E. (2017). Why are the mathematics national examination items difficult and what is teachers' strategy to overcome it? International Journal of Instruction, 10(103), 257-276. https://doi.org/10.12973/iji.2017.10317a

Retnawati, H., Munadi, S., Arlinwibowo, J., Wulandari, N., \& Sulistyaningsih, E. (2017). Teachers' difficulties in implementing thematic teaching and learning in elementary schools. The New Educational Review, 48(2), 201-212. https://doi.org/10.15804/tner.2017.48.2.16

Rodrigues, A., Montague, K., Nicolau, H., \& Guerreiro, T. (2015). Getting smartphones to talkback: Understanding the smartphone adoption process of blind users. ASSETS 2015 - Proceedings of the 17th International ACM SIGACCESS Conference on Computers and Accessibility, October, 23-32. https://doi.org/10.1145/2700648.2809842

Roe, J., \& Webster, A. (2002). Children with visual impairments. Routledge.

Saefi, M., Lukiati, B., \& Suarsini, E. (2017). Developing android-based mobile learning on cell structure and functions lesson subject topic to optimize grade XI students' cognitive comprehension. Jurnal Pendidikan Sains, 5(2), 57-63.

Said, K., Kurniawan, A., \& Anton, O. (2018). Development of media-based learning using android mobile learning. Journal of Theoretical and Applied Information Technology, 96(3), 668-676.

Salisbury, R. (2008). Teaching pupils with vidual Impairment: A guide to making the school curriculum accessible. Routledge.

Sari, A. C., Fadillah, A. M., Jonathan, J., \& Prabowo, M. R. D. (2019). Interactive gamification learning media application for blind children using android smartphone in Indonesia. Procedia Computer Science, 157, 589-595. https://doi.org/10.1016/j.procs.2019.09.018

Sarkar, R., \& Das, S. (2012). Analysis of different braille devices for implementing a cost-effective and portable braille system for the visually impaired people. International Journal of Computer Applications, 60(9), 1-5. https://doi.org/10.5120/9717-3073

Sayal, R., Subbalakhmi, C., \& Saini, H. S. (2020). Mobile app accessibility for visually impaired. International Journal of Advanced Trends in Computer Science and Engineering, 9(1), 182-185. https://doi.org/10.30534/ijatcse/2020/27912020

Shetake, P. S., Patil, S. A., \& Jadhav, P. M. (2014). Review of text to speech conversion methods. International Journal of Industrial Electronics and Electrical Engineering, 2(28), 2347-6982.

Stanimirov, K. M., Grbovic, A. B., Dimoski, S. M., \& Jorgic, B. M. (2020). Physical activities of people with visual Impairment and their determining factor. Specijalna Edukacija $i$ Rehabilitacija, 19(2), 91-107. https://doi.org/10.5937/specedreh19-26366

Supandi, Ariyanto, L., Kusumaningsih, W., \& Aini, A. N. (2018). Mobile phone application for mathematics learning. Journal of Physics: Conference Series, 983(1), 1-5. https://doi.org/10.1088/1742-6596/983/1/012106

Tamhane, K., Khan, W. T., Tribhuwan, S. R., Burke, A. P., \& Take, S. B. (2015). Mobile Learning Application. International Journal of Scientific and Research Publications, 5(3), 1-4.

Ţepelea, L., Gavriluţ, I., Tiponuţ, V., Szolgay, P., \& Gacsádi, A. (2014). OCR application on smartphone for visually impaired people. Journal of Electrical and Electronics Engineering, 7(1), $153-156$.

Trance, N. J. C., Marapo, R. B., \& Pornel, J. B. (2012). Students' visual representation of mathematics students' visual representation of mathematics. Journal of The Korean Association For Science Education, 32(8), 1318-1332. https://doi.org/10.14697/jkase.2012.32.8.1318 
Venkateswarlu, S., Kamesh, D. B. K., Sastry, J. K. R., \& Rani, R. (2016). Text to speech conversion. Indian Journal of Science and Technology, 9(38), 1-3. https://doi.org/10.17485/ijst/2016/v9i38/102967

Westwood, P. (2009). What teachers need to know about students with disabilities. ACER Press.

World Health Organization. (2012). Global data on visual impairments 2010. World Health Organization. https://www.who.int/blindness/GLOBALDATAFINALforweb.pdf

Zurqoni, Retnawati, H., Arlinwibowo, J., \& Apino, E. (2018). Strategy and implementation of character education in senior high schools and vocational high schools. Journal of Social Studies Education Research, 9(3), 370-397. https://doi.org/10.17499/jsser.01008 